http://jmscr.igmpublication.org/home/

ISSN (e)-2347-176x ISSN (p) 2455-0450

crossref DOI: https://dx.doi.org/10.18535/jmscr/v7i8.141

Journal Of Medical Science And Clinical Research

IGM Publication

An Official Publication of IGM Publication

\title{
Clinico \& Histomorphological Spectrum of Lesions of Cervix, a one year Prospective study in a Tertiary Care Hospital
}

\author{
Authors \\ Nidhi Gupta, Mamta Gupta, Arvind Khajuria, Narinder Mohan
}

\begin{abstract}
Majority of the specimens which reach the histopathology laboratory are from gynecology department. Aim of this study is to determine the frequency and histomorphological patterns of lesions of the cervix in various age groups. This is a prospective study done in a tertiary care hospital. A total of 110 cases were received in histopathology department and evaluated. The age group of the patients was between 22-78 years. It was concluded that about $80.90 \%$ cases were non-neoplastic and $19.10 \%$ were neoplastic. The most common of all these lesions was chronic non-specific cervicitis.

Keywords: Cervicitis, neoplastic, non-neoplastic.
\end{abstract}

\section{Introduction}

The cervix is prone to develop many nonneoplastic and neoplastic gynaecological lesions. These lesions are most commonly found in women of reproductive age group. Gynaecological specimens from the substantial proportion of the workload in most of the Histopathology Departments of most of the laboratories. Colposcopic examination of cervix with cervical cytology is very frequently used to screen the cervical lesions but the histopathological examination of the cervical lesions is the single best gold standard for the diagnosis. HPV cervicitis is a causal risk factor for condyloma acuminatum, preinvasive cervical intraepithelial neoplasia (CIN I, II, III) and eventually cancer (Bayo $\mathbf{S}$ et al, 2002). Chronic non specific cervicitis is a frequently encountered lesion both clinically and in histopathological specimens. (Craig $P$ et al, 2003). Studies have shown that chronic granulomatous cervicitis is mostly caused by tuberculosis. (Chakraborty $\mathbf{P}$ et al, 1995). Type 16 is the most common HPV type in invasive cancer and in $\mathrm{CIN}-2$ and $\mathrm{CIN}-3$ and is found in $47 \%$ of women in both categories (John AR et al, 2003). The low grade lesion corresponds to CIN 1, whereas the high grade lesion corresponds to CIN11 and CIN 111 (Rosai J , 2011). Carcinoma cervix accounts for $2 \%$ of all cancers in women and so represents the second most frequent gynaecological malignancy in the world (Hausen HZ, 2002). The peak age of occurrence of cervical cancers in between 55 and 59 years. Cervical Cancer is ranked as the most frequent cancer in women in India. It is estimated that in the year 2005, there were about 520,000 cervical cancer cases in the World, of which 443,000 are in the Developing countries (National Cancer Registry Programme, 2006). The current estimates indicate approximately 1,32,000 new cases diagnosed and 74,000 deaths annually in India, accounting to nearly $1 / 3^{\text {rd }}$ of the global 
cervical cancer deaths (WHO/ICO, 2007). Though the Carcinoma Cervix is the second most common gynaecological malignancy globally, the incidence of Carcinoma Cervix is decreased from $33.8 \%$ to $25.96 \%$ (National Cancer Registry Programme, 2006). The present study was an effort to explore, elucidate and document lesions affecting the uterine cervix. ASCOMS is a tertiary care teaching hospital where we received a lot of hysterectomy as well as cervix biopsy specimens. Such study gave a fairly good idea of spectrum of cervical lesions. There have been similar studies from various regions, but there was paucity of data of such lesions. This study has been helpful to determine frequency and histopathological features of different types of benign and malignant lesions of Uterine Cervix.

\section{Material \& Methods}

The study was conducted in the Post Graduate Department of Pathology. The material consisted of all the hysterectomy and cervical biopsy specimens. A total of 110 cases were included after due permission from the Institutional Ethics Committee. Written informed consent was obtained from all patients and was enrolled according to the following inclusion and exclusion criteria.

\section{Inclusion Criteria}

1) Hysterectomy specimens

2) Cervical biopsy specimens

\section{Exclusion Criteria}

1) Autolysed Specimens.

2) Inadequate biopsies.

All specimens submitted were properly labelled, numbered and fixed overnight in $10 \%$ buffered formalin. After fixation, detailed gross examination was carried out. Sections from the representative areas of specimen were prepared .Special stains were carried out, wherever required. The statistical analysis was done and the result was expressed as percentages and other appropriate statistical methods were applied wherever necessary.

\section{Results}

A total of 110 cases of lesions of uterine cervix were studied, of which $89(80.90 \%)$ were non neoplastic and 21(19.10\%) were neoplastic. The specimens received were Hysterectomy (90) (81.81\%) and cervical biopsy (20) (18.19\%).

The ages of the patients ranged from 22 to 78 years. majority of the patients were between 3140 years accounting for 38 cases (34.54\%), followed by 28 cases (25. 45\%) between $41-50$ years, 23 case $(20.90 \%)$ between $21-30$ years, 16 cases (14.54\%) between 51-60 years, 4 cases $(3.67 \%)$ between $61-70$ years and 1 case $(0.90$ $\%$ ) above 70 years.

Among the 110 uterine cervix specimens, the commonest finding was unremarkable cervix seen in 63 cases $(57.27 \%)$ followed by mass in cervix seen in 20 cases ( $18.18 \%$ ), erosion in 15 cases (13.63\%), nabothian cyst in 8 cases $(7.27 \%$ ) and polyp in 4 cases $(3.65 \%)$.

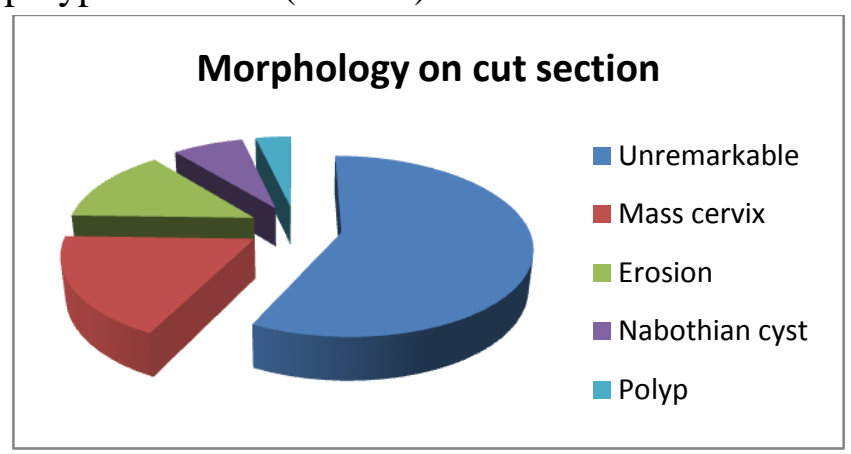

Out of 110 cervical lesions, there were 89 non neoplastic lesions, out of these 89, $75(68.18 \%)$ were inflammatory lesions and $14(12.62 \%)$ were non neoplastic glandular lesions.

21 neoplastic lesions were studied, out of which $15(13.75 \%)$ were malignant, and only $6(5.45 \%)$ were benign.

Table 1: Showing distribution of various cervical lesions

\begin{tabular}{|c|c|c|c|}
\hline S. No & Cervical lesions & No .of cases & Percentage \\
\hline & Non neoplastic & & \\
\hline 1. & Inflammatory & 75 & $68.18 \%$ \\
\hline 2. & $\begin{array}{c}\text { Non neoplastic } \\
\text { cervical glandular } \\
\text { lesions }\end{array}$ & 14 & $12.62 \%$ \\
\hline & Neoplastic & & \\
\hline 1. & Malignant & 15 & $13.75 \%$ \\
\hline 2. & Benign & 06 & $5.45 \%$ \\
\hline Total & & 110 & $100 \%$ \\
\hline
\end{tabular}


The most common histopathological diagnosis among 110 cervical lesions was Chronic non specific cervicitis comprised of 73 cases $(66.36 \%)$ followed by Carcinoma seen in 15 cases (11.86\%), Nabothian cyst seen in 8 cases $(7.27 \%)$, Cervical fibroid seen in 4 cases $(4.54 \%)$, Endocervical polyp in 4 cases (4.54\%), Tuberculosis of cervix, Microglandular hyperplasia, condyloma each comprised of 2 cases $(1.81 \%)$. In this study, the most common histologic variant of carcinoma was Squamous cell carcinoma which comprised of 13 cases $(86.6 \%)$ out of all 15 malignancies followed by 1 each case of Adenocarcinoma (6.7\%) and HSIL $(6.7 \%)$.Age of the patients with Carcinoma ranged from 25 -68 years. Majority of the patients were between 31-40 years accounting for 6 cases (40\%) out of total 15 malignancies, followed by 3 cases $(20 \%)$ each in the age group 41-50 years \& 51-60 years, 2 cases $(13.34 \%)$ in age group 61-70 years and only 1 case $(6.66 \%)$ in 21-30 years age group. Occurrence of large cell non-keratinizing squamous cell carcinoma (SCC) was highest $(61.53 \%)$, followed by keratinizing squamous cell carcinoma $(23.07 \%)$ and small cell non keratinizing squamous cell carcinoma (15.4\%).

Table 2: Distribution of Histopathological lesions

\begin{tabular}{|l|c|c|c|}
\hline S.No & $\begin{array}{c}\text { Histopathological } \\
\text { lesion }\end{array}$ & $\begin{array}{c}\text { No. of } \\
\text { cases }\end{array}$ & Percentage \\
\hline 1. & $\begin{array}{c}\text { Chronic non } \\
\text { specific cervicitis }\end{array}$ & 73 & $66.36 \%$ \\
\hline 2. & Carcinoma & 15 & $11.86 \%$ \\
\hline 3. & Nabothian cyst & 08 & $7.27 \%$ \\
\hline 4. & Cervical fibroid & 04 & $4.54 \%$ \\
\hline 5. & Endocervical polyp & 04 & $4.54 \%$ \\
\hline 6. & Tuberculosis cervix & 02 & $1.81 \%$ \\
\hline 7. & $\begin{array}{c}\text { Microglandular } \\
\text { hyperplasia }\end{array}$ & 02 & $1.81 \%$ \\
\hline 8. & Condyloma & 02 & $1.81 \%$ \\
\hline Total & & $\mathbf{1 1 0}$ & $\mathbf{1 0 0} \%$ \\
\hline
\end{tabular}

Table 3: Distribution of non neoplastic \& neoplastic lesions according to age groups

\begin{tabular}{|l|c|c|c|c|c|c|}
\hline Age (in years ) & $21-30$ & $31-40$ & $41-50$ & $51-60$ & $61-70$ & Above 70 \\
\hline Non neoplastic lesions & 21 & 30 & 22 & 13 & 2 & 1 \\
\hline Percentage & $91.30 \%$ & $78.94 \%$ & $78.57 \%$ & $81.25 \%$ & $50 \%$ & $100 \%$ \\
\hline Neoplastic & & & & & & \\
\hline Benign & 1 & 2 & 3 & 0 & 0 & 0 \\
\hline Malignant & 1 & 6 & 3 & 3 & 2 & 0 \\
\hline Percentage & $8.7 \%$ & $21.06 \%$ & $21.43 \%$ & $18.75 \%$ & $50 \%$ & $0 \%$ \\
\hline Total & $\mathbf{1 0 0 \%}$ & $\mathbf{1 0 0 \%}$ & $\mathbf{1 0 0 \%}$ & $\mathbf{1 0 0 \%}$ & $\mathbf{1 0 0 \%}$ & $\mathbf{1 0 0 \%}$ \\
\hline
\end{tabular}

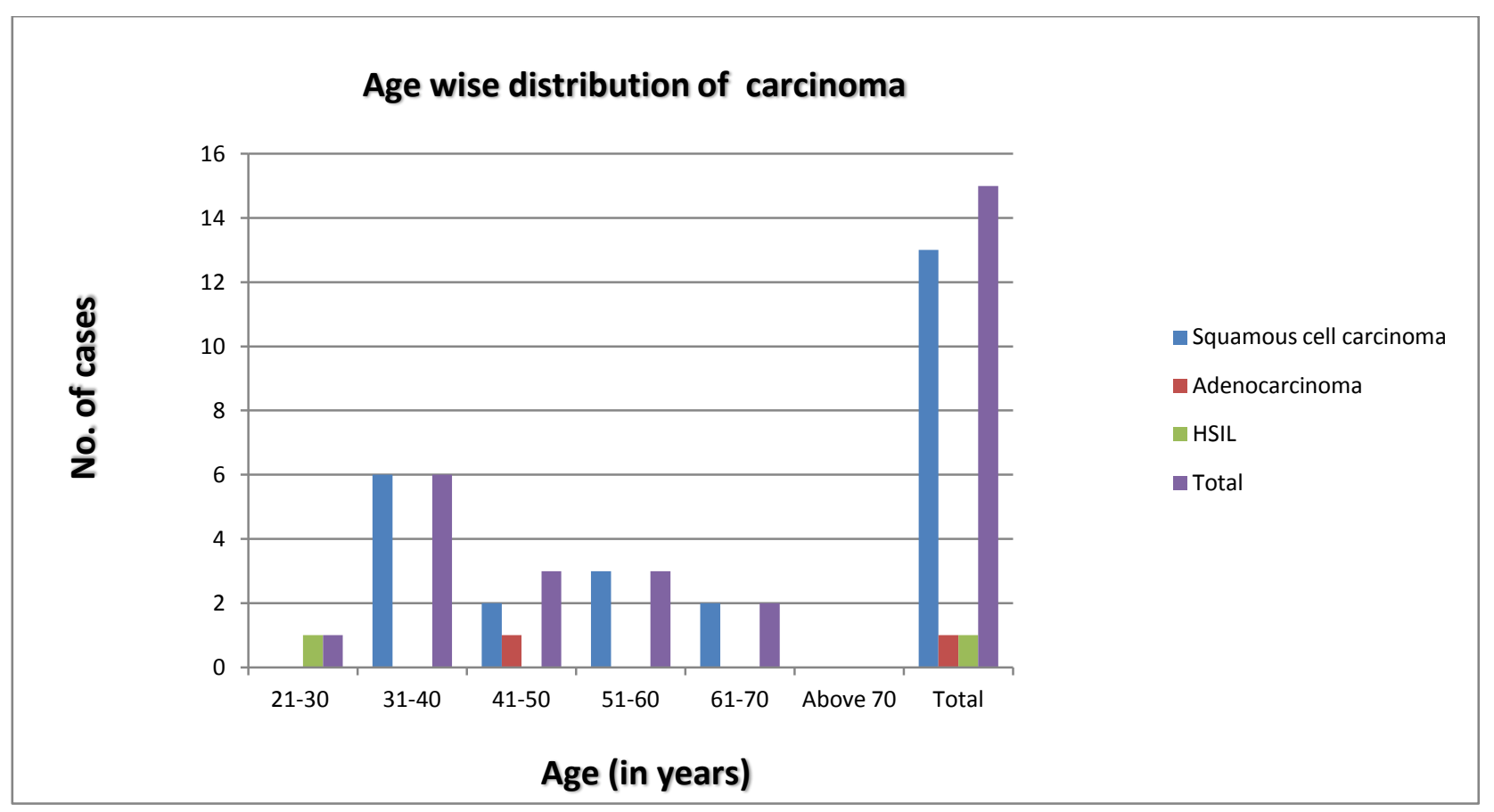




\section{JMSCR Vol||07||Issue||08||Page 830-837||August}

Table 4: Age wise distribution of grading of squamous cell carcinoma (SCC)

\begin{tabular}{|l|c|c|c|c|}
\hline Age (yrs) & $\begin{array}{c}\text { Well differentiated } \\
\text { SCC }\end{array}$ & $\begin{array}{c}\text { Moderately differentiated } \\
\text { SCC }\end{array}$ & $\begin{array}{c}\text { Poorly differentiated } \\
\text { SCC }\end{array}$ & Total \\
\hline $21-30$ & 0 & 0 & 0 & 0 \\
\hline $31-40$ & 1 & 2 & 3 & 6 \\
\hline $41-50$ & 0 & 1 & 1 & 2 \\
\hline $51-60$ & 0 & 2 & 1 & 3 \\
\hline $61-70$ & 0 & 1 & 1 & 2 \\
\hline$>70$ & 0 & 0 & 0 & 0 \\
\hline
\end{tabular}
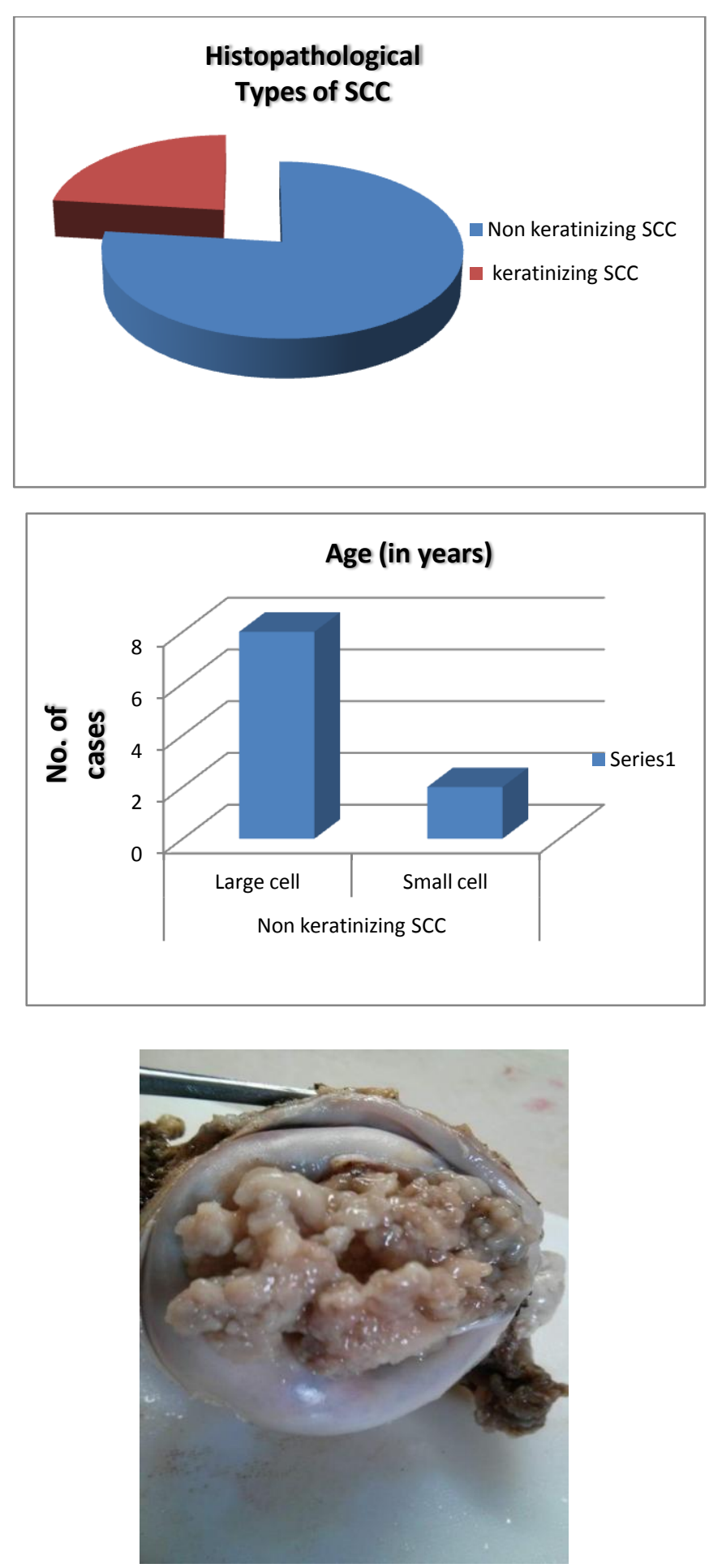

Fig 1 Gross image of Adeocarcinoma

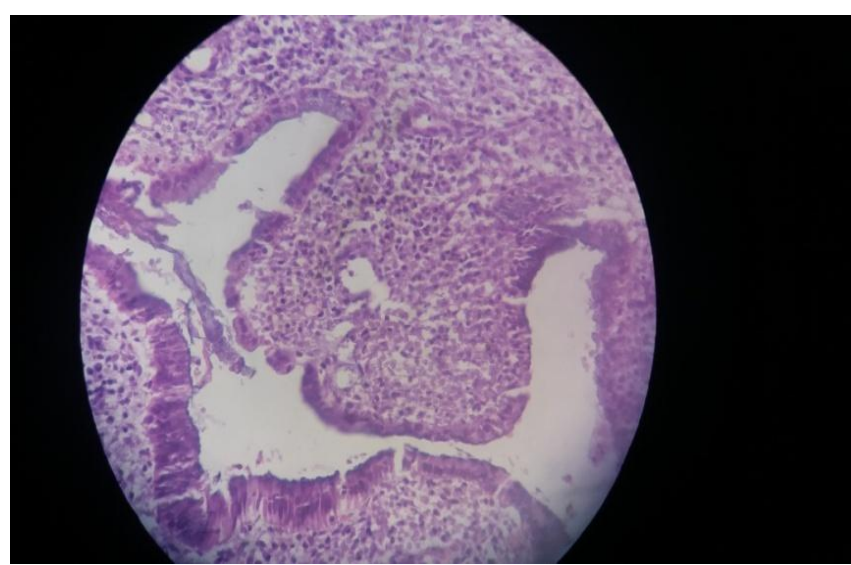

Fig 2 Chronic Cervicitis

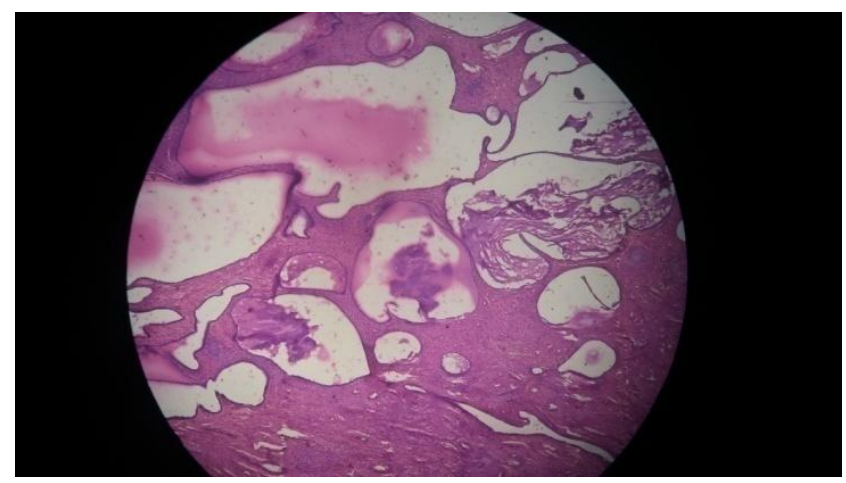

Fig 3A Endocervical Polyp

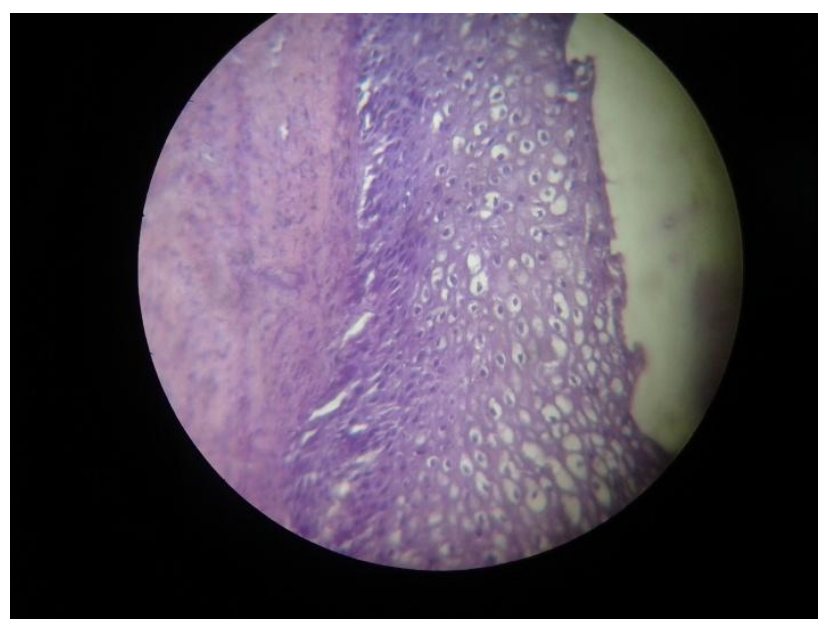

Fig 3B Koilocytosis 


\section{JMSCR Vol||07||Issue||08||Page 830-837||August}

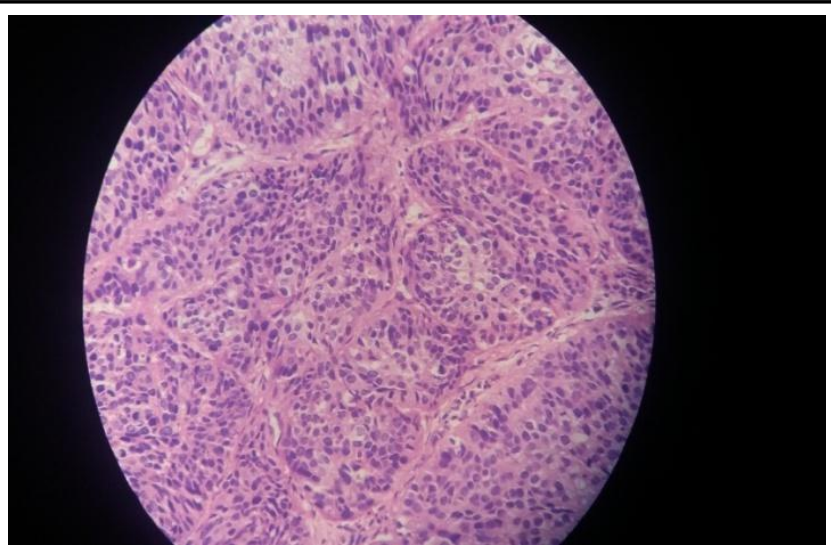

Fig 4 Squamous cell carcinoma

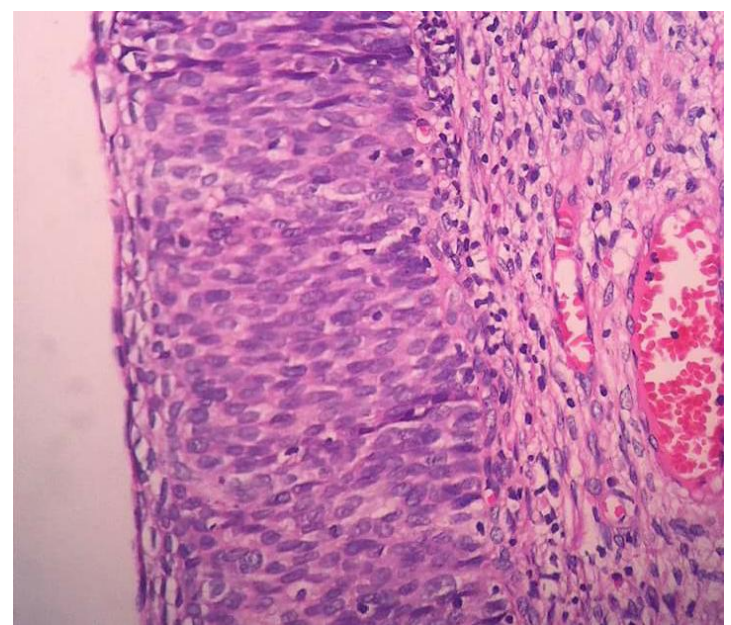

Fig 5 HSIL

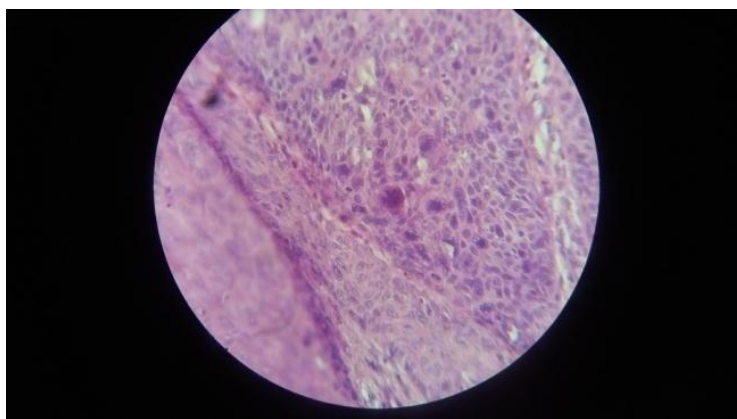

Fig 6 Squamous cell carcinoma showing atypical mitosis

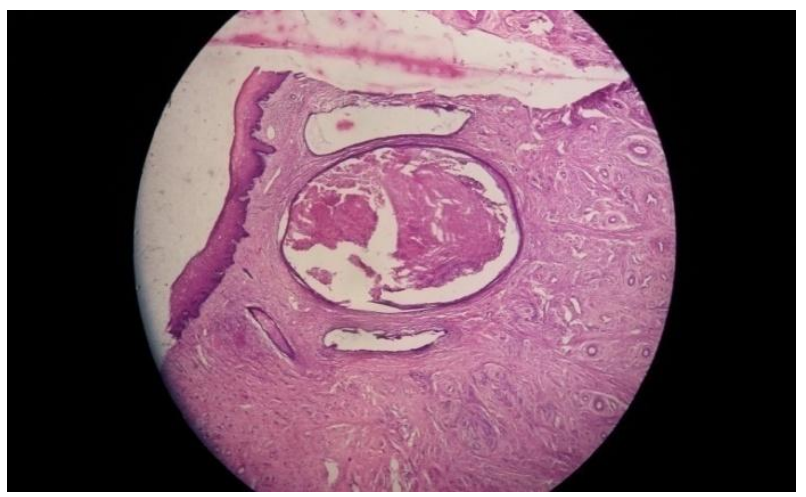

Fig 7 Nabothian Cyst

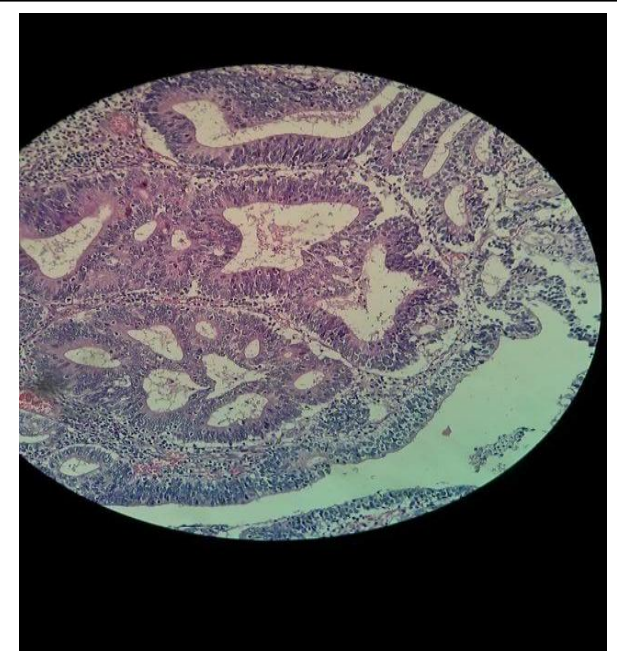

Fig 8 Adenocarcinoma of cervix

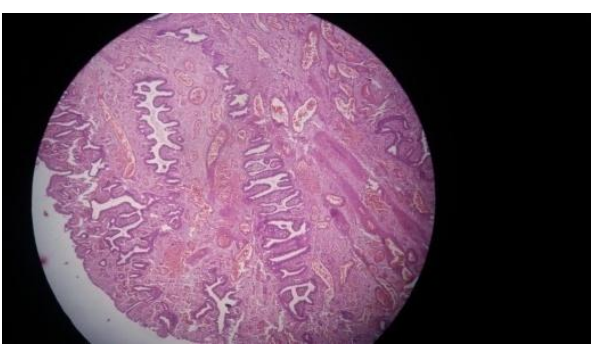

Fig 9 Microglandular Hyperplasia

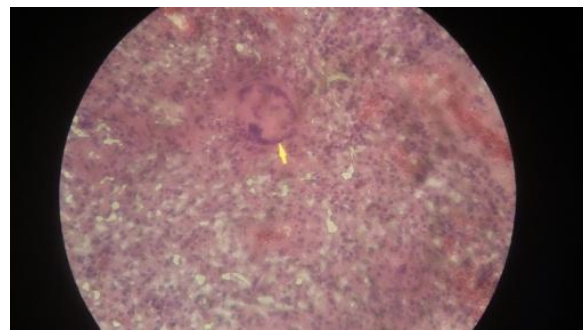

Fig 10 Langhan's Giant cell in Tuberculosis

\section{Discussion}

Over the period of one year study, department of pathology received 110 cervical specimens. Cervical specimens form a significant part of surgical pathology section of this department. Poste $P$ et al, 2015 also found the same finding $(16.01 \%)$ in their study carried out in Gulbarga district. Hysterectomy was the most common specimen $(81.81 \%)$ received in our study as well as Poste $P$ et al, 2015 and Srivani et al, 2015 study. In this study, out of total 110 cases, $80.90 \%$ accounted for non neoplastic lesions, and $19.10 \%$ for neoplastic lesions respectively which is approximately comparable to the study of FN Nwachokor et al, 2013 studied 176 specimens, of these, $56.3 \%$ were benign lesions while $43.7 \%$ 
were malignant. Among the benign cases, nonneoplastic lesions accounted for $92.9 \%$ of benign cervical lesion. Inflammatory lesions and tumour like lesions accounted for $59.8 \%$ and $40.2 \%$ of non-neoplastic cervical lesions respectively. These findings were similar to that observed by Srikanth S, $2016 \quad 32.8 \%$ between 31-40 years and $0.8 \%$ above 70 years and Pallipady A et al, 2011 in which majority of the patients were in the $4^{\text {th }}$ decade of life (47\%). Discharge per vagina was the commonest presenting symptom seen in 39 patients $(35.45 \%$, followed by irregular menses in 19 patients ( $17.27 \%)$, post coital bleed in 16 patients $(14.58 \%)$, pain abdomen in 14 patients $(13.0 \%)$ infertility in 12 patients $(10.61 \%)$ and mass per vagina in 10 patients $(9.09 \%)$ which was similar to study conducted by Garewal J et al, 2016 ,Kumar NVJ et al, 2013 and Pallipady A et al, 2011

Out of 110 cervical lesions, there were 89 non neoplastic lesions, out of these 89, $75(68.18 \%)$ were inflammatory lesions and 14 (12.62\%) were non neoplastic glandular lesions which was similar to the study conducted by Saravanan $\mathbf{S}$ et al, 2015 which showed that Non-inflammatory tumor like condition such as endocervical polyp was a rare entity, constituting only $6.5 \%$ of the total cervical specimens studied. 21 neoplastic lesions were studied, out of which 15 ( $13.75 \%)$ were malignant, and only $6(5.45 \%)$ were benign similar to the study of Garewal J et al, 2016 in which neoplastic lesions comprised of $8.68 \%$ of the total 311 cases of cervical lesions studied The most common histopathological diagnosis among 110 cervical lesions was Chronic non specific cervicitis comprised of 73 cases $(66.36 \%)$ which is similar to the to the study conducted by Pandit GA et al, 2016 in which 371 cases (61.83\%) cases comprised of chronic non specific cervicitis and Garewal J et al, 2016 (79.74\%) Similar results were obtained by Saravanan $\mathbf{S}$ et al, 2015 (58.6\%). similar studies were also conducted by Gausia et al, 2013 , Poste P et al, 2015 and Solapurkar et al, 1985.CNSC is rare before menarche or after menopause, this finding in our study correlated with the study of Lowe et al, 1988. Endocervical polyp was seen in 4 cases (4.54\%) which is in coordination with the study conducted by Poste P et al, 2015 (4.68\%) and Pandit GA et al, 2016 (3.66\%). Cervical fibroid was seen in 4 cases $(4.54 \%)$, however this result was contrary to the study conducted by Poste $\mathbf{P}$ et al, $2015(1.5 \%)$ and Pandit GA et al, 2016 $(0.6 \%)$. This may be due to the fact of more estrogen exposure as oral contraceptives or hormonal imbalance. However further studies need to be conducted to identify the proper etiology of this entity. Nabothian cyst was observed in 8 cases $(7.27 \%)$ which are in accordance to the study conducted by Jyothi et al, 2009 which found that cervical inflammatory lesions with associated changes showed Nabothian cysts in about $6.71 \%$ but contrary to the study conducted by Garewal $\mathbf{J}$ et al, 2016 who found nabothian cyst in $19.7 \%$ cases.

Condyloma was seen in 2 cases $(1.81 \%)$ which is almost similar to the study conducted by Garewal J et al, 2016 in which $1.2 \%$ cases comprised of condyloma and Srikanth S, 2016 in which there is $1.90 \%$ cases had condyloma.

Microglandular hyperplasia and TB cervix however were a less common finding comprised of $1.8 \%$ each which is similar to the study conducted by Pallipady A et al, 2011 who found $2.1 \%$ of microglandular hyperplasia in their study.

None of these patients gave history of oral contraceptive use. Majority of the patients who gave history of $\mathrm{MH}$ were in the $4^{\text {th }}$ decade of life. However in contrast study done by Chumas et al, 1985 who evaluated cervices over a period of 3 years found 43 cases of $\mathrm{MH}$, reported that more than half of the patients had no history of the use of oral contraceptives.

In this study, the most common histologic variant of carcinoma was Squamous cell carcinoma which comprised of 13 cases (86.6\%) out of all 15 malignancies which is in coordination with the study conducted by Srikanth S, 2016 in which $84 \%$ cases comprised of Squamous cell 
carcinomas followed by 1 each case of Adenocarcinoma (6.7\%) which is in accordance with the study conducted by Pandit GA et al, 2016 which have 1 case of Adenocarcinoma but this finding was contrary to the study conducted by Srikanth S, 2016 who concluded only 1.9\% cases of Adenocarcinoma. And 1 case of HSIL (6.7\% was present which is similar to the study of Saravanan $\mathbf{S}$ et al, 2015 in which there were $7.6 \%$ cases who were diagnosed with HSIL.

Age of the patients with Carcinoma ranged from $25-68$ years. Majority of the patients were between 31-40 years accounting for 6 cases (40\%) which is similar to the study conducted by Jain A et al, 2014 which concluded that occurrence of Squamous cell carcinoma was early during $4^{\text {th }}$ decade. In the study done by Dhakal et al, 2009 occurrence of Squamous cell carcinoma was during $5^{\text {th }}$ decade. This is in contrast to the study done by us and this may be due to the fact of possible risk factors affecting a certain age range of population or due to the various geographical areas. Occurrence of Poorly-differentiated Squamous cell carcinoma was highest as compared to well and Moderately differentiated Squamous cell carcinoma (46\%) which is in coordination with the study conducted by Jain A et al, 2014 who studied the occurrence of this in $50 \%$ cases, while in study done by done by Husin $\mathbf{N}$ et al, 2011 highest occurrence of Moderately differentiated carcinoma (44.9\%) was noted and in study done by Abudu EK et al, 2006 highest occurrence of Well differentiated carcinoma $(39 \%)$ was noted.

Occurrence of Poorly differentiated squamous cell carcinoma was early during 4th decade which is in contrary to the study done by Saravanan $\mathbf{S}$ et al, 2015 in which occurrence of poorly differentiated carcinoma is in the $5^{\text {th }}$ decade but was in accordance with the study of Pandit GA et al, 2016 in which the incidence of Poorly differentiated carcinomas was also highest in the $4^{\text {th }}$ decade.

Occurrence of Large cell Non-Keratinizing Squamous cell carcinoma (NKSCC) was the commonest type of all (61.53\%) which are similar to the various studies conducted by Pandit GA et al, 2016, Poste P et al, 2015, Gupta et al, 1979 and Solapurkar et al, 1985.

\section{Conclusion}

In the present study of lesions of Uterine Cervix, non neoplastic lesions were the commonest. Chronic non specific cervicitis $(66.36 \%)$ was the commonest diagnosis followed by carcinoma (11.86\%).Among carcinomas, Squamous cell carcinoma $(86.6 \%)$ was the commonest entity. Occurrence of Poorly differentiated carcinoma was the highest. Large cell Non Keratinizing Squamous Cell Carcinoma was the commonest histological type of cancer. Microglandular Hyperplasia, Condyloma and TB cervix were less common finding seen only in $4.84 \%$ each. These observations and results proved to be valuable baseline information regarding histopathological features of lesions of Uterine Cervix in our population. More studies, to define the risk factors in our population and to identify specific etiological factors are recommended. The spectrum of cervical lesions is vast and therefore early detection and management of certain lesions can help in reducing the morbidity.

\section{References}

1. Bayo S, Bosch FX, de Sanjose S, Munoz N, Combita AL, Coursaget P, et al. Risk factors of invasive cervical cancer in Mali. Int $\mathbf{J}$ Epidemiol 2002 Feb; 31(1):202-9.

2. Chakraborty P, Roy A, Bhattacharya S, Addhya S, Mukherjee S. Tuberculous Cervicitis: A clinicopathological \& bacteriological study. J Indian Med Assoc 1995;93:167-8.

3. Chumas JC. Microglandular hyperplasia of the uterine cervix. Obstet Gynaecol. 1985;66: 406-9.

4. Craig P, Lowe D. Non neoplastic lesions of cervix. In: Fox H, Well M editors. Haines and Taylor Obstetrical and Gynaecological Pathology $5^{\text {th }}$ ed. Edinburgh Churchill Livingstone 2000; 273-91. 
5. Dhakal HP, Pradhan M. Histological patterns of gynaecological cancers. J Nepal Med Assoc, 2009;48(176):301-5.

6. FN Nwachokor, GC Forae Morphological spectrum of non- neoplastic lesions of the uterine cervix in Warri, South-South, Nigeria.2013 v( 16) pg-429-432.

7. Garewal J, Khatri SL, Saxena V, Gupta S, Singh S, Dubey K. Clinicopathological evaluation of non neoplastic and neoplastic lesions of uterine cervix. Imp J Interdisciplinary Res,2016;2(4) : 426-30.

8. Gousia R, Gupta Y, Bhardwaj S. Patterns of lesions in hysterectomy specimens. A prospective study. JKscience:Vol 15 No. 2 April - June, 2013.

9. Gupta S, Rao S, Gupta VP. Cervix correlated cytohistological study, 1979.Indian J patho microbio 22;93-6.

10. Hausen HZ. Papilloma viruses and cancer; from basic studies to clinical application. Nat Rev Cancer 2: 342-50 (May,2002).

11. Husin N, Helali T, Domi M, Bedri S, Cervical cancer in women diagnosed at the national health laboratory, sudden: A call for screening, Sudan journal of medical science, 2011; (6): 183-190

12. Jain A, Jain R, Iqbal, Koteeswran G. Histopathological study of tumors of cervix. ACRT 05, 1:2,2014.

13. John AR, Howard WJ. Te Linde's operative gynaecology Lippincott Williams \& Wilkins Publishers 2003;9:1377.

14. Jyothi et al. Retrospective and prospective study of cervical lesions. ( Dissertation); Dr. N.T.R. University of health sciences Vijaywada, Andhrapradesh, 2009.

15. Kumar BJ, Annam V. Clinico pathological study of non neoplastic lesions of uterine cervix with their histopathological categorization Int J sc res, 2013;6 : 2094-8.

16. National Cancer Registry Programme. Consolidated reports of the population based cancer registeries 2001-04. Indian council of medical research, New Delhi, 2006.

17. Pallipady A, Illanthodi S, Vaidhya R, Ahmed Z, Suvarna R, Metkar G. A Clinico morphological spectrum of the non neoplastic lesions of the uterine cervix at AJ Hospital, Mangalore. J Clinic Diagn Res 2011; 5(3); 546-50.

18. Panday k., Bhagoliwal A.J., A cancer cervix need for mass surveillance program specially in rural areas, Obstet gynecol India, 2005; 55(5): 436-439.

19. Pandit GA, Khiste JA, Jindal S. Study of histomorhological spectrum of lesions of uterine cervix. Int $\mathbf{J}$ current research, 2016;8(05);30724-7.

20. Poste P, Patil A, Andola SK. Incidence of Neoplastic Cervical Pathologies Recorded at a Medical College. VOL 2, NO 2(2015), International Annals of Advanced Scientific Research.

21. Rosai J; Uterus-Cervix; Rosai and Ackerman's Surgical Pathology; $10^{\text {th }}$ edition; volume 2;2011;Elseiver;1436-76.

22. Saravanan S, Arnold J, Arul P. Histomorphological spectrum of lesions of the cervix, a retrospective study in a tertiary care hospital. J evol Med Dent Sci, 2015; 4(59):10326-9.

23. Schneider V. Arias -Stella reaction of the endocervix: frequency and location. Acta Cytol. 1981,May- Jun;25(3): 224-8.

24. Solapurkar ML. Histological study of uterine cervix in malignant and benign lesions. J Obstet Gynecol Ind 1985; 35:933.

25. Srikanth S. Spectrum of cervical lesions observed in 500 cases: Carcinoma Cervix the leading cause of death in females. Ind $\mathbf{J}$ Cancer, Jan- March,2016;53(1).

26. WHO/ICO Information Centre on HPV and Cervical Cancer(HPV Information centre). Summary report on HPV and Cervical Cancer statistics in India, 2007 [ last assessed on 2008,May 1]. 